\title{
Low diacylglycerol values in colonic adenomas and colorectal cancer
}

\author{
G Sauter, A Nerlich, U Spengler, R Kopp, A Pfeiffer
}

\begin{abstract}
The biochemical events that make colonic epithelial cells proceed along the adenomacarcinoma sequence are not well understood. The phosphoinositol signal transduction pathway is involved in the regulation of cell growth and differentiation. To determine its role in colonic neoplasias we performed mass measurements of its second messenger sn-1,2diacylglycerol in biopsy specimens from normal mucosa and neoplasias of the colon. Normal colonic mucosa was also investigated in patients without colonic abnormalities $(\mathbf{n}=10)$. Compared with pooled diacylglycerol values from five colonic sites $(100 \%)$, values in patients with a normal colon were highest in the ascending colon $(120(5) \%, p<0.05)$ and lowest in the rectum $(81(5) \%, p<0.01)$. Absolute diacylglycerol values in patients with normal colons $(2.62(0 \cdot 16) \mathrm{nmol} / \mathrm{mg}$ protein) were not significantly different from those found in the normal mucosa of patients with colorectal neoplasias $(2.45(0.17) \mathrm{nmol} / \mathrm{mg}$ protein). Both colonic adenomas $(n=15)$ and colorectal carcinomas $(n=14)$ showed significantly decreased diacylglycerol values compared with the adjacent normal mucosa of each patient $(72(4) \%, p<0.001$, and $71(4) \%$, p $<0.001$ respectively). The appreciable decrease in mass diacylglycerol values clearly distinguishes adenomas and carcinomas of the colon from the surrounding normal mucosa. This finding suggests that profound metabolic changes of the phosphoinositol signal transduction pathway occur early in the adenomacarcinoma sequence and may be important in colonic carcinogenesis.
\end{abstract}

Colonic adenoma and colorectal cancer are regarded as successive stages in the multistep process of colonic carcinogenesis. The biochemical events that cause colonic epithelial cells to escape normal growth control mechanisms and proceed along the adenoma-carcinoma sequence are, however, largely unknown. Recent research has suggested a role for signal transduction mechanisms in the control of cell growth and differentiation. ${ }^{1-4}$ In particular, sn-1,2-diacylglycerol, which is generated in the polyphosphoinositide second messenger system by the action of phospholipase $\mathrm{C},{ }^{5}$ has been shown to mediate signals of cell proliferation and differentiation by activation of protein kinase C. ${ }^{167}$

Tumour promoters of the phorbol ester family bypass this signalling pathway to activate protein kinase $\mathrm{C}$ directly by binding to the diacylglycerol site. ${ }^{189}$ Experimentally induced activation of protein kinase $\mathrm{C},{ }^{10}$ suggests that it may enhance either cell differentiation ${ }^{31-17}$ or proliferation, ${ }^{18}{ }^{19}$ depending on the tissue investigated.

Involvement of the phosphoinositol signal transduction pathway in the process of cell transformation is further supported by the fact that oncogene products like $\mathrm{p} 60^{\mathrm{v}-\mathrm{src}}$, polyoma middle T antigen, p68 ${ }^{v-r o s}, p^{v-f m s}, p^{v-f e s}$, and p2 $1^{\text {ras }}$ may influence or act as enzymes of this pathway. ${ }^{20-22}$ On the other hand, some cellular protooncogenes such as c-fos ${ }^{2324}$ and c-myc ${ }^{25}$ are potential targets of protein kinase $\mathrm{C}$ action.

To gain a better understanding of changes in the phosphoinositol signal transduction pathway during the adenoma-carcinoma sequence, we investigated the role of the second messenger molecule sn-1,2-diacylglycerol using biopsy specimens from patients with adenomas and carcinomas of the colon. Measurements were performed in biopsy specimens from normal mucosa, colonic adenomas, and colorectal adenocarcinomas. Diacylglycerol values in the colonic mucosa of patients with normal colons were also determined, since increased cell proliferation has been reported recently in the normal mucosa of patients with adenomas or carcinomas of the colon. ${ }^{26}$

We report low diacylglycerol values in adenomas and carcinomas of the colon compared intraindividually with the normal mucosa. Absolute values showed interindividual variations that were approximately two fold but were within narrow limits when measured intraindividually along five colonic sites. Absolute diacylglycerol values in normal mucosa of patients with colorectal neoplasms did not differ significantly from values observed in patients with normal colons.

\section{Materials and methods}

\section{PATIENTS}

Twenty nine patients who were found to have polyps or cancer of the colon during colonoscopy were studied. In addition, we examined biopsy specimens from 10 patients with normal colons who had undergone colonoscopy during routine diagnostic evaluation to exclude colonic disease (positive occult blood test, abdominal pain of unknown origin, irritable bowel syndrome, haemorrhoidal bleeding). All patients had given written informed consent to the study, which was approved by the local ethics committee.

Before colonoscopy about 4-6 1 of irrigation solution were given orally, and gut irrigation finished when the effluent was clear. The composition of the irrigation fluid was as follows: $6 \cdot 34 \mathrm{~g}$ polyethyleneglycol $4000,0.42 \mathrm{~g}$ sodium sulfate, $0.17 \mathrm{~g}$ sodium bicarbonate, $0.15 \mathrm{~g}$ sodium chloride, and $0.07 \mathrm{~g}$ potassium chloride added to 
$100 \mathrm{ml}$ of water. The time between the end of irrigation and the first biopsy was about one hour.

\section{BIOPSY SPECIMENS}

Five biopsy specimens were taken with an endoscopic miniforceps from each site investigated. In patients with adenomas or carcinomas, biopsy specimens were taken as paired samples, from the tumour and from flat normal looking mucosa $10-20 \mathrm{~cm}$ away. In patients with normal colons, biopsy specimens were taken from the ascending, transverse, descending, and sigmoid colon and from the rectum. One sample of each biopsy specimen was always preserved for histological examination. Immediately after removal, the biopsy specimens were frozen at $-70^{\circ} \mathrm{C}$ on dry ice. This was done because pilot studies have shown that diacylglycerol is rapidly metabolised - values drop to $35-40 \%$ after storage for half an hour at $0^{\circ} \mathrm{C}$.

\section{HISTOLOGICAL EXAMINATION}

Polyps and cancers were classified by histological examination into the following subgroups: tubular adenomas with moderate cellular atypias $(\mathrm{n}=5)$ or severe cellular atypias $(\mathrm{n}=1)$; tubulovillous adenomas with moderate $(n=7)$ or severe $(n=1)$ atypias; villous adenomas $(n=1)$; differentiated adenocarcinomas $(n=12)$; and undifferentiated adenocarcinomas $(n=2)$. The stromal part of the biopsy specimen preserved for histological examination was semiquantitatively determined. Patients were excluded from the study if stromal tissue exceeded $40 \%$. Stromal parts were 10.3 $(1 \cdot 2) \%, 12 \cdot 1(1 \cdot 8) \%$, and $21 \cdot 2(2 \cdot 8) \%$ in normal mucosa, adenomas, and carcinomas respectively. To test the influence of the stromal part on diacylglycerol values, biopsy specimens were assigned to three groups - group I, stromal part $0-10 \%$, group II, stromal part $11-25 \%$, and group III, stromal part $26-40 \%$. No significant difference between these groups was found with regard to diacylglycerol values in normal mucosa $(\mathrm{p}=0.4)$, adenomas $(\mathrm{p}=0.64)$, and carcinomas $(\mathrm{p}=0 \cdot 11)$.

\section{LIPID EXTRACTION}

A modification of the method of Bligh and Dyer ${ }^{27}$ was used to extract phospholipids and neutral lipids. After the wet weight of the frozen biopsy specimens had been determined, tissue samples were quickly placed in $3.9 \mathrm{ml}$ of chloroform/ methanol/phosphate buffered saline (1:2:0.9 $\mathrm{v} / \mathrm{v} / \mathrm{v})$ at $0^{\circ} \mathrm{C}$. The samples were then homogenised under $\mathrm{N}_{2}$ with a Polytron PTA 10 TS homogeniser (Bachhofer, Reutlingen, West Germany) for 15 seconds and the monophases were mixed. After adding $1 \mathrm{ml}$ of chloroform and $1 \mathrm{ml}$ phosphate buffered saline and centrifugation at $3000 \mathrm{~g}$ for five minutes, the chloroform phases were saved. The phosphate buffered saline/methanol and solid phases were washed once with $2 \mathrm{ml}$ of chloroform and the chloroform extracts were combined. For determination of diacylglycerol three aliqouts of the chloroform extracts were dried under $\mathrm{N}_{2}$; one aliqout was stored at $-20^{\circ} \mathrm{C}$ for determination of phospholipids. For the analysis of the protein content of the samples, the resting aqueous phase containing a solid pellet was centrifuged again, the supernatant was discarded, and $1 \mathrm{ml}$ of $1 \mathrm{M}$ $\mathrm{NaOH}$ was added for alkaline proteolysis. The mixture was brought to $95^{\circ} \mathrm{C}$ for 30 minutes, cooled, and then adjusted to $\mathrm{pH} 6.5$ by adding $1 \mathrm{M} \mathrm{HCl}$.

\section{QUANTITATIVE ASSAY FOR SN-1,2-}

\section{DIACYLGLYCEROL}

Diacylglycerol was determined quantitatively as recently described by Preiss et al..$^{28}$ Briefly, diacylglycerol was quantitatively converted to [32P] phosphatidic acid using recombinant Escherichia coli sn-1,2-diacylglycerol kinase (Lipidex Inc, Westfield, NY, USA) and [ $\left.{ }^{32} \mathrm{P}\right]$ adenosine triphosphate. The phosphatidic acid thus formed was re-extracted as described above and the chloroform phase washed with $1 \%$ $\mathrm{HClO}_{4}$. Phosphatidic acid was separated on silica-gel 60 plates (Merck) and spots corresponding to phosphatidic acid were scraped into scintillation vials. Radioactivity was quantitated by ligand scintillation spectrophotometry. The amount of diacylglycerol present in the original samples was calculated from the sample volumes and the specific activity of the adenosine triphosphate used, corrected by the factor 1.4 since recovery studies had shown that about $29 \%$ of the phosphatid acid had been lost during lipid extraction and washing with $\mathrm{HClO}_{4}$.

When known amounts of sn-1,2-dioleoylglycerol were assayed as described above, the assay was strictly linear in the range of $100 \mathrm{pmol}$ to $10 \mathrm{nmol}$. The intra-assay coefficient of variation was less than $0.08(n=3)$ and the interassay coefficient of variation was less than $0 \cdot 12(n=3)$.

\section{PROTEIN AND PHOSPHOLIPID ASSAY}

After $\mathrm{NaOH}$-hydrolysis of proteins as described above, the protein content of the biopsy specimens was determined in a protein microassay (Bio-Rad, Munich). Phospholipids were determined as recently described by van Veldhoven and Mannaerts. ${ }^{9}$

\section{CALCULATION OF SN-1,2-DIACYLGL YCEROL}

To calculate diacylglycerol values the tissue wet weight, protein, and phospholipid contents of each sample were determined. Protein/tissue ww ratios of normal mucosa, adenomas, and carcinomas corresponded well with each other (mean (SEM) 0.108 $(0.006) \mathrm{mg} / \mathrm{mg}, 0 \cdot 112(0.01)$ $\mathrm{mg} / \mathrm{mg}$, and $0.097(0.007) \mathrm{mg} / \mathrm{mg}$ respectively). Phospholipids were decreased in carcinomas if they were calculated on the basis of phospholipid/ protein ratios (mean (SEM) 230.6 (10.6) $\mathrm{nmol} / \mathrm{mg}, 226 \cdot 1(22 \cdot 8) \mathrm{nmol} / \mathrm{mg}$, and $200 \cdot 8$ $(22 \cdot 4) \mathrm{nmol} / \mathrm{mg}$ respectively) or as phospholipid/ tissue ww ratios (mean (SEM) $23.7 \quad(4 \cdot 6)$ $\mathrm{nmol} / \mathrm{mg}, 24 \cdot 0 \cdot(2 \cdot 1) \mathrm{nmol} / \mathrm{mg}$, and $18 \cdot 4(1 \cdot 6)$ $\mathrm{nmol} / \mathrm{mg} \quad(\mathrm{p}<0.05)$ respectively). A similar decrease in phospholipid had been observed in hepatoma cell lines and the Friend erythroleukemic cell line when cells were compared with 
their differentiated counterparts. ${ }^{30} 31$ Since phospholipid did not seem to represent a reliable basis on which diacylglycerol values could be calculated in these different tissues, values were related to the protein content of the samples. Diacylglycerol values are given as $\mathrm{nmol} / \mathrm{mg}$ protein. No attempt was made to calculate diacylglycerol values on the basis of tissue DNA, since hyperploid states of neoplastic tissues may falsify differences in cellularity of the tissues investigated.

\section{STATISTICAL ANALYSIS}

The diacylglycerol values of adenomas and carcinomas were compared with the values in adjacent normal mucosa using Student's $t$ test for paired samples. For unpaired samples the MannWhitney test was used. To test the influence of the stromal part on diacylglycerol values, biopsy specimens were assigned to three different groups on the basis of their stromal contents (see 'Histological examination'). Differences in diacylglycerol values between these three groups were tested by the Kruskal-Wallis test. Data are given as mean (SEM).

\section{Results}

DIACYLGLYCEROL VALUES IN MUCOSA OF PATIENTS WITH NORMAL COLONS

In 10 patients (two men and eight women aged 28 to 71 years, mean (SEM) $52(4.9)$ years), diacylglycerol values were determined in the epithelium of the ascending, transverse, descending, and sigmoid colon and the rectum, which had been shown to be histologically normal. When values from all sites were pooled for each patient, the diacylglycerol/protein values were mean (SEM) $2.62(0.16) \mathrm{nmol} / \mathrm{mg}$ (range $1.92 \mathrm{nmol} /$ $\mathrm{mg}-3.49 \mathrm{nmol} / \mathrm{mg}$ ). Diacylglycerol/tissue ww ratios were $219 \cdot 7(25 \cdot 7) \mathrm{pmol} / \mathrm{mg}$. No correlation between diacylglycerol values and age or sex of the patients was found. Contrasting with the twofold interindividual range, intraindividual differences between different colonic sites lay within narrow limits. They probably reflected a constant distribution of diacylglycerol in tissue (Fig 1), which was highest in the ascending colon and lowest in the rectum. Values for the five sites, from the ascending colon to the rectum, were mean (SEM) $3.06(0.2) \mathrm{nmol} / \mathrm{mg}, 2.62(0.2)$ $\mathrm{nmol} / \mathrm{mg}, 2.54(0.2) \mathrm{nmol} / \mathrm{mg}, 2.70(0.2) \mathrm{nmol} /$ $\mathrm{mg}$, and $2.07(0.08) \mathrm{nmol} / \mathrm{mg}$ respectively. Differences were significant for the ascending colon $(p<0.05)$ and the rectum $(p<0.01)$ compared with the pooled diacylglycerol values from the five colonic sites.

DIACYLGLYCEROL VALUES IN THE NORMAL MUCOSA OF PATIENTS WITH ADENOMAS OR CARCINOMAS

Biopsy specimens, taken as paired samples from histologically normal mucosa about $10-20 \mathrm{~cm}$ away from any lesion and from the lesion itself, were available from 15 patients with colonic adenomas (transverse colon $n=3$, descending colon $n=3$, sigmoid colon $n=9$ ) and from 14

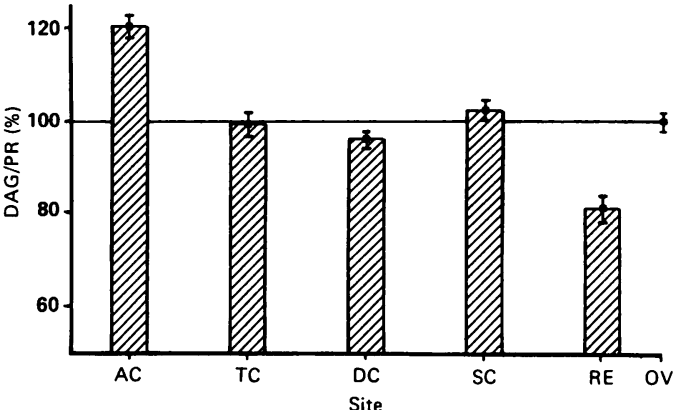

Figure 1: Distribution of sn-1,2-diacylglycerol/protein values $(D A G / P R)$ in different parts of the colon.

$A C=$ ascending colon, $T C=$ transverse colon,

$D C=$ descending colon,$S C=$ sigmoid colon,$R E=$ rectum $O V=$ overall values.

Values are expressed as the percentage of DAG/PR ratios in each site related to pooled ratios from the five colonic sites investigated in each subject.

patients with colorectal cancer (ascending colon $n=7$, sigmoid colon $n=5$, rectum $n=2$ ). Overall diacylglycerol/protein ratios were mean (SEM) $2 \cdot 22(0 \cdot 17) \mathrm{nmol} / \mathrm{mg}$ in patients with adenomas and $2 \cdot 70(0 \cdot 30) \mathrm{nmol} / \mathrm{mg}$ in those with colorectal cancer. These values were not significantly different from those found in the colonic mucosa of normal control patients $(2.62(0 \cdot 16) \mathrm{nmol} /$ $\mathrm{mg})$.

\section{DIACYLGLYCEROL VALUES IN PATIENTS WITH} ADENOMAS

Values were determined as paired samples from adjacent normal mucosa and colonic adenomas (tubular adenomas $\mathrm{n}=6$, tubulovillous adenomas $\mathrm{n}=8$, villous adenomas $\mathrm{n}=1$ ) of 15 patients (nine men, six women), whose ages ranged from 41 to 81 years (mean (SEM) 62 (4) years). Locations of the adenomas were as indicated above. Tissue diacylglycerol values in the normal mucosa were mean (SEM) $2.22(0.17) \mathrm{nmol} / \mathrm{mg}$ (range 1.26 $3.7 \mathrm{nmol} / \mathrm{mg}$ ). Colonic adenomas showed consistently low values compared with the surrounding normal mucosa $(1.58(0.13) \mathrm{nmol} / \mathrm{mg}$, $\mathrm{p}<0.001)$. This reduction was found in tubular, tubulovillous, and villous adenomas $(1.79(0.18) \mathrm{nmol} / \mathrm{mg}, 1.42(0.19) \mathrm{nmol} / \mathrm{mg}$, and $1.52 \mathrm{nmol} / \mathrm{mg}$ respectively). These tissue diacylglycerol contents were $71 \cdot 3(7 \%), 73 \cdot 7(6) \%$, and $58(0) \%$ for tubular, tubulovillous, and villous adenomas respectively compared with the surrounding normal mucosa. No correlation between the size of the adenomas and the diacylglycerol values was found. No further reduction in diacylglycerol/protein ratios was found in adenomas with severe cellular atypias (Fig 2).

DIACYLGLYCEROL VALUES IN CARCINOMAS Samples from differentiated $(n=12)$ and undifferentiated $(n=2)$ adenocarcinomas were obtained from 14 patients (six men, eight women) whose ages ranged from 30 to 78 years (mean 62 (3) years). Locations of the carcinomas were as indicated above. Absolute diacylglycerol values of the adjacent normal mucosa and colorectal carcinomas, which were determined as paired samples, were mean (SEM) $2 \cdot 71(0 \cdot 3)$ and $1.95(0.27) \mathrm{nmol} / \mathrm{mg}(\mathrm{p}<0.001)$ respectively. 


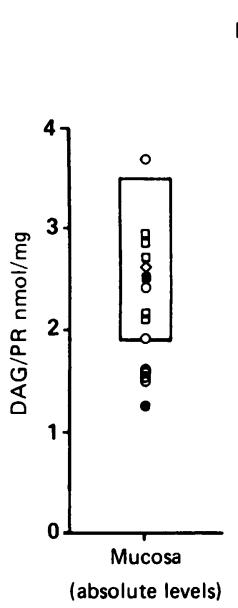

Relative levels

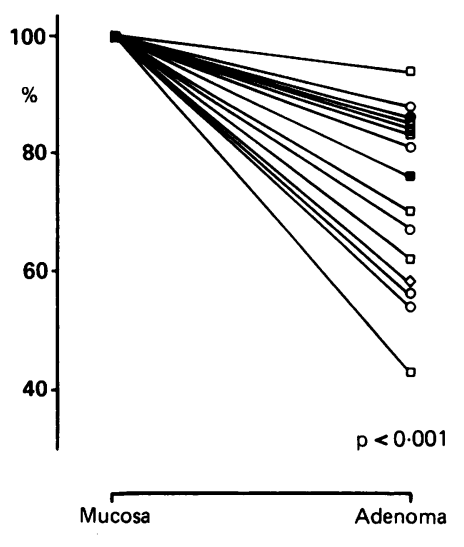

Figure 2: Values of sn-1,2-diacylglycerol/protein (DAG/PR)

found in normal mucosa and in colonic adenomas.

Left: absolute DAG/PR values found in normal mucosa

$10-20 \mathrm{~cm}$ away from the adenoma $(\square=$ tubular,

$\bigcirc=$ tubulovillous, $\rangle=$ villous adenoma, closed

symbols = severe cellular atypias). DAG/PR values found in

patients with normal colons lie within the rectangle.

Right: relative $D A G / P R$ values in adenomas expressed as percentages of values found in the normal mucosa of each patient (paired samples)

Expressed as a percentage of the adjacent normal mucosa diacylglycerol/protein ratios were 70.5 (4)\% (Fig 3). This decrease was more pronounced in undifferentiated $(57 \cdot 5(10) \%)$ than in differentiated adenocarcinomas $(72 \cdot 7(4) \%)$.

\section{Discussion}

Extensive experimental work indicates that the phosphoinositol signal transduction pathway may play a role in the regulation of cell growth and differentiation' and may be affected by the action of various oncogenes. To learn more about the metabolism of this signal transduction pathway in spontaneously occurring tumours we performed quantitative measurements of its second messenger sn-1,2-diacylglycerol in colonic adenomas and colorectal carcinomas. Diacylglycerol values were determined in the normal mucosa of patients without colonic
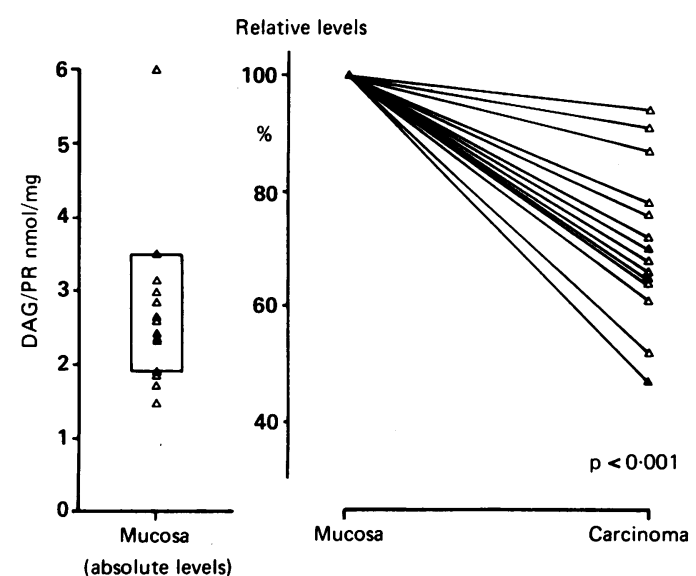

Figure 3: Values of sn-1,2-diacylglycerol/protein (DAG/PR) found in normal mucosa and in colorectal carcinomas.

Left: absolute DAG/PR values found in normal mucosa $10-20 \mathrm{~cm}$ away from the carcinoma $(\triangle=$ differentiated carcinoma, $\mathbf{\Delta}=$ undifferentiated carcinoma). DAG values in patients with normal colons are within the rectangle.

Right: relative DAG/PR values in carcinomas expressed as percentages of values found in the normal mucosa of each patient (paired samples). abnormalities, in the normal mucosa of patients with adenomas or carcinomas, and in the adenomas and carcinomas themselves.

Diacylglycerol values in the unaffected colon were usually highest in the ascending colon and lowest in the rectum. This distribution does not correlate with the pool size of proliferating cells as reported by Terpstra, ${ }^{26}$ who observed a decrease in the rectum but no increase in the right colon. One possible explanation is that diacylglycerol may be associated with specialised functions of cells rather than representing a proliferative marker. Further investigations are needed, however, to elucidate this.

To our knowledge, no mass measurements of diacylglycerol in human tissues that allow comparison between values found in our tissue specimens with those of other human organs or tumours have been reported. Our values in the normal colonic mucosa $(219 \cdot 7(25 \cdot 7) \mathrm{pmol} / \mathrm{mg}$ tissue ww or $2.62(0.16) \mathrm{nmol} / \mathrm{mg}$ protein) were comparable with those reported in animal tissues. Bocckino $^{32}$ found a tissue content of 113-156 $\mathrm{ng} / \mathrm{mg} \mathrm{ww}(180-220 \mathrm{pmol} / \mathrm{mg} \mathrm{ww})$ in rat hepatocytes and Dixon ${ }^{33}$ reported values of 213-289 $\mathrm{pmol} / \mathrm{mg} \mathrm{ww}$ (calculated by given specific activity) in minilobules of the mouse pancreas. These data indicate that the second messenger diacylglycerol represents a highly preserved component of the cell which seems to be held relatively constant with regard to the protein content.

Doctrow has recently shown that activation of protein kinase $\mathrm{C}$ by phorbol esters suppresses the effects of angiogenic mitogens and may promote differentiation in bovine capillary endothelial cells. ${ }^{13}$ Activation of protein kinase $\mathrm{C}$ has further been shown to inhibit cell proliferation and to induce differentiation in cultured keratinocytes. ${ }^{3212}$ On the other hand, increased proliferation has been reported in rat colonic epithelial cells, which had been stimulated by high concentrations of 12-0-tetradecanoylphorbol-13-acetate. ${ }^{34}$

Our study shows a highly consistent reduction in diacylglycerol values in colorectal neoplasias compared with the adjacent colonic mucosa from the same subjects. This reduction seems to occur early during the multistep process of colonic carcinogenesis, since diacylglycerol values were low in all of the adenomas. This decrease is unlikely to be due to methodological problems, since connective tissue contents were not significantly increased in adenomas compared with normal mucosa (see 'Histological examination') and there was no correlation between the extent of connective tissue infiltration and decrease of diacylglycerol values in the tissues investigated. Moreover, we did not see a reduction in other parameters such as epidermal growth factor receptors ${ }^{35}$ or activity of phospholipase C (unpublished observation) in adenomas compared with normal mucosa.

Diacylglycerol functions physiologically as the major activator of the $\mathrm{Ca}^{2+}$ - and phospholipid dependent enzyme protein kinase $\mathrm{C}$. Decreased values suggest therefore a decreased activation of protein kinase $\mathrm{C}$ in colorectal neoplasias. This hypothesis is supported by recent results from our laboratory indicating reduced protein kinase $\mathrm{C}$ activity in colonic adenomas and colorectal 
carcinomas (submitted data). Enhanced conversion of diacylglycerol to biologically active metabolites, which might explain the decreased values observed in colonic neoplasias, cannot, however, be ruled out..$^{36}$ Among these, lipoxin A and some other eicosanoids are known to activate protein kinase $\mathrm{C}$ to some extent. ${ }^{1037}$ Metabolites of diacylglycerol like phosphatidic acid and prostaglandin F2 $\alpha$ have further been shown to induce cell proliferation in 3T3 fibroblasts, independent of the activation of protein kinase C. ${ }^{38}$ Whether breakdown products of diacylglycerol could be important in the regulation of cell growth and differentiation remains to be determined. We have no reason to assume, however, that enhanced cell proliferation and dedifferentiation in colonic neoplasias is mediated by increased generation of diacylglycerol activating protein kinase $\mathrm{C}$ directly.

Terpstra $^{26}$ reported enhanced cell proliferation in the normal looking mucosa of patients with large adenomas and carcinomas of the colon. Increased activity of ornithine decarboxylase, which is thought to be associated with proliferation, has been observed, even in the normal mucosa of patients with adenomas or cancer. ${ }^{39}$ Although this abnormality may be associated with the development of colonic neoplasias, it does not seem to be the specific event causing colonic epithelial cells to form neoplasias. ${ }^{39}$ In contrast, the appreciable reduction in diacylglycerol values distinguished colonic neoplasias from the surrounding normal mucosa. This finding suggests profound metabolic changes in the phosphoinositol signal transduction pathway in cells that proceed along the adenoma-carcinoma sequence.

This work was supported by the Friedrich-Baur-Stiftung, University of Munich grant $25 / 87$ and the Wilhelm-SanderStiftung, Munich.

1 Nishizuka $Y$. The role of protein kinase $C$ in cell surface signal transduction and tumor promotion. Nature 1984; 308: 693-8.

2 Chambard JC, Paris S, L'Allemain G, Pouysségur J. Two growth factor signalling pathways in fibroblasts distinguished by pertussis toxin. Nature $1987 ; 326: 800-3$.

3 Jaken S, Yuspa SH. Early signals for keratinocyte differentiation: role of $\mathrm{Ca}^{2+}$-mediated inositol lipid metabolism in tion: role of $\mathrm{Ca}^{2+}$-mediated inositol lipid metabolism in normal and $1033-8$.

4 Berridge MJ, Brown KD, Irvine RF, Heslop JP. Phosphoinositides and cell proliferation. $\mathcal{F}$ Cell Sci 1985; 3 (suppl): 187-95

5 Majerus PW, Connolly TM, Deckmyn H, et al. The metabolism of phosphoinositide-derived messenger molecules. Science 1986; 234: 1519-26.

6 Moolenaar WH, Tertoolen LGJ, de Laat SW. Phorbol esters and diacylglycerol mimic growth factors in raising cytoplasmatic pH. Nature 1984; 312: 371-4.

7 Rozengurt E. Early signals in the mitogenic response. Science 1986; 234: 161-6.

8 Hannun YA, Bell RM. Phorbol ester binding and activation of protein kinase $C$ in Triton $X-100$ mixed micelles containing protein kinase C in Triton X-100 mixed micelles co.

9 Blumberg PM. Protein Kinase C as the receptor for the phorbol ester tumor promoters: Sixth Rhoads Memorial phorbol ester tumor promoters: Sixth R

10 Nishizuka Y. Studies and perspectives of protein kinas C. Science 1986; 233: 305-12.

11 Krieg L, Kühlmann I, Marks F. Effects of tumor-promoting phorbol esters and of acetic acid on mechanisms controlling DNA synthesis and mitosis (chalones) and on the biosynthesis of histidine-rich protein in mouse epidermis. Cancer Res 1974; 34: 3135-46.
12 Yuspa SH, Ben T, Hennings $H$. The induction of epiderma transglutaminase and terminal differentiation by tumor promoters in cultured epidermal cells. Carcinogenesis 1983; 4: 1413-8.

13 Doctrow SR, Fokman J. Protein kinase $\mathrm{C}$ activators suppress stimulation of capillary endothelial cell growth by angiogenic endothelial mitogens. F Cell Biol 1987; 104: 679-87.

14 Huang $\mathrm{CH}$, Ives $\mathrm{HE}$. Growth inhibition by protein kinase $\mathrm{C}$ late in mitogenesis. Nature 1987; 329: 849-50.

15 Huberman E, Callaham MF. Induction of terminal differentiation in human promyelocytic leukemia cells by tumo promoting-agents. Proc Natl Acad Sci USA 1979; 76: 1293-7.

16 Rosoff PM, Stein LF, Cantley LC. Phorbol esters induce differentiation in a pre-B-lymphocyte cell line by enhancing $\mathrm{Na}^{\prime} / \mathrm{H}^{\prime}$ Exchange. $\mathcal{F}$ Biol Chem 1984; 259: 7056-60.

17 Ebeling JG, Vandenbark GR, Kuhn LJ, Ganong BR, Bell RM, Niedel JE. Diacylglycerols mimic phorbol diester induction of leukemic cell differentiation. Proc Natl Acad Sci USA 1985; 82: 815-9.

18 Kaibuchi K, Takai Y, Nishizuka Y. Protein kinase C and calcium ion in mitogenic response of macrophage-depleted human peripheral lymphocytes. F Biol Chem 1985; 260. 1366-9.

19 Rozengurt E, Rodriguez-Pena A, Coombs M, Sinnett-Smith J. Diacylglycerol stimulates DNA-synthesis and cell division in mouse 3T3-cells: Role of $\mathrm{Ca}^{-}$-sensitive phospholipiddependent protein kinase. Proc Natl Acad Sci USA 1984;81: 5748-52.

20 Macara IG. Oncogenes, ions, and phospholipids. Am $\mathcal{F}$ Physiol 1985; 248: C3-C11.

21 Whitman M, Kaplan DR, Schaffhausen B, Cantley L, Roberts TM. Association of phosphatidylinositol kinase activity with polyoma middle-T competent for transformation. Nature polyoma middle-T

22 Jackowski S, Rettenmier CW, Sherr CJ, Rock CO. A guanine nucleotide-dependent phosphatidylinositol 4,5-diphosphat phospholipase $\mathrm{C}$ in cells transformed by the $\mathrm{v}$-fms and $\mathrm{v}$-fe oncogenes. F Biol Chem 1986; 261: 4978-85.

23 Greenberg ME, Ziff EB. Stimulation of 3T3 cells induces transcription of the c-fos proto-oncogene. Nature $1984 ; 311$ : 433-8

24 Verma IM, Sassone-Corsi P. Proto-oncogene fos: Complex but versatile regulation. Cell $1987 ; 51: 513-4$.

25 Faletto DL, Arrow AS, Macara IG. An early decrease in phosphatidylinositol turnover occurs on induction of Friend phosphatidylinositol turnover occurs on induction of Friend expression. Cell 1985; 43; 315-25.

26 Terpstra OT, van Blankenstein $M$, Dees J, Eilers GAM Abnormal pattern of cell proliferation in the entire colonic mucosa of patients with colon adenoma or cancer. Gastroenterology 1987; 92: 704-8.

27 Bligh EG, Dyer WJ. A rapid method of total lipid extraction and purification. Can f Biochem Physiol 1959; 37: 911-7.

28 Preiss J, Loomis CR, Bishop WR, Stein R, Niedel JE, Bell $\mathrm{RM}$. Quantitative measurement of sn-1,2-diacylglycerols present in platelets, hepatocytes, and ras- and sistransformed normal rat kidney cells. $f$ Biol Chem 1986; 261. $8597-600$.

29 Van Veldhoven PP, Mannaerts GP. Inorganic and organic phosphate measurements in the nanomolar range. Anal Biochem 1987; 161: 45-8.

30 Zwingelstein G, Tapiero $\mathrm{H}$, Portoukalian J, Fourcade A. Changes of phospholipid and fatty acid composition in differentiated Friend leukaemic cells. Biochem Biophys Res Commun 1981; 98: 349-58.

31 Galeotti T, Borrello S, Minotti G. Membrane alterations in cancer cells. Ann N Y Acad Sci 1986; 488: 469-89.

32 Bocckino SB, Blackmore PF, Exton JH. Stimulation of 1,2 diacylglycerol accumulation in hepatocytes by vasopressin epinephrine, and angiotensin II. 7 Biol Chem 1985; 260: 14201-7.

33 Dixon JF, Hokin LE. Secretogogue-stimulated phosphatidylinositol breakdown in the exokrine pancreas liberates arachidonic acid, stearic acid, and glycerol by sequential arachidonic acid, stearic acid, and glycerol by sequential actions of phospholipase C

34 Craven PA, DeRubertis FR. Subcellular distribution of protein kinase $C$ in rat colonic epithelial cells with different proliferative activities. Cancer Res 1987; 47: 3434-8.

35 Rothbauer E, Mann K, Wiebecke B, et al. Epidermal growth factor receptors and epidermal growth factor-like activity in colorectal mucosa, adenomas and carcinomas. Klin Wochenschr 1989; 67: 518-23.

36 Bennett A, Civier A, Hensby CN, Melhuish PB, Stamford IF Measurement of arachidonate and its metabolites extracted from human normal and malignant gastrointestinal tissues. Gut 1987; 28: 315-8.

37 Hansson A, Serhan CN, Haeggström J, Ingelman-Sundberg $M$, Samuelsson B. Activation of protein kinase $C$ by lipoxin $\mathrm{A}$ and other eicosanoids. Biochem Biophys Res Commun $A$ and other eicosanc

38 Yu CL, Tsai MH, Stacey DW. Cellular ras activity and phospholipid metabolism. Cell 1988; 52: 63-71.

39 Luk GD, Baylin SB. Ornithine decarboxylase as a biological marker in familial colonic polyposis. $N$ Engl f Med 1984; 311: 80-3. 